\title{
RESEARCH PAPER \\ Diversity and distribution of the Aegorhinus genus in the La Araucanía Region of Chile, with special reference to $A$. superciliosus and $A$. nodipennis
}

\section{Andrea Zavala ${ }^{1}$, Mario Elgueta ${ }^{2}$, Juan Abarzúa ${ }^{1}$, Alfonso Aguilera ${ }^{1}$, Andrés Quiroz ${ }^{3}$, and Ramón Rebolledo ${ }^{1}$}

${ }^{1}$ Facultad de Ciencias Agropecuarias y Forestales. Universidad de La Frontera. Casilla 54-D. Temuco, Chile. ${ }^{2}$ Museo Nacional de Historia Natural. Santiago, Chile. Casilla 787, Santiago, Chile.

${ }^{3}$ Facultad de Ingeniería, Ciencias y Administración. Universidad de La Frontera. Casilla 54-D. Temuco, Chile.

\begin{abstract}
A. Zavala, M. Elgueta, J. Abarzúa, A. Aguilera, A. Quiroz, and R. Rebolledo. 2011. Diversity and distribution of the Aegorhinus genus in the La Araucanía Region of Chile, with special reference to $A$. superciliosus and $A$. nodipennis. Cien. Inv. Agr. 38(3): 367-377. The Araucanía region is a berry producing area where important behavioral aspects of species in the genus Aegorhinus, a pest that affects crops, are still unknown. The objectives of this study were to determine the distribution, abundance and richness of these species in agroecological zones of La Araucanía Region and to determine the hosts in which they were found. The sites where these species were found were represented on a map divided into grids of $25 \times 25 \mathrm{~km}$. Eight species of Aegorhinus were found in the area, and Aegorhinus nodipennis and Aegorhinus superciliosus were the most abundant. The diversity was analyzed using the Shannon-Wiener index, and the equitability was determined using the Pielou index. The agroecological zone with the greatest diversity of the region corresponded to mountain ranges; however, the central plain registered the highest abundance of individuals. This study introduces new hosts for six of the eight species found in the region.
\end{abstract}

Key words: Aegorhinus, agroecological zones, Coleoptera, hosts.

\section{Introduction}

Aegorhinus Erichson and Alastoropolus Kuschel are the only genera of the Aterpini tribe (Coleoptera: Curculionidae) in South America (Elgueta and Marvaldi, 2006). In Chile, they are located from the central to the southernmost zones, i.e., from $32^{\circ} 02^{\prime}$ to $53^{\circ} 08^{\prime}$ south latitude.

Received February 24, 2010. Accepted June 9, 2011. Corresponding author: adzavala@uc.cl
Similarly, they can be found in the Andean forests of southern Argentina (Morrone and Roig-Juñent, 1999). Within this tribe, the Aegorhinus genus is the most diverse and contains 24 species (Kuschel, 1951; Cekalovic, 1970; Elgueta, 2000). Moreover, A. superciliosus, A. nodipennis and A. phaleratus constitute major agricultural pests in Chile. $A$. superciliosus is considered the most important species in La Araucanía region due to its negative impact on the production of berries (Aguilera, 1988, 1990). Most species are associated with 
deciduous forests and Valdivian temperate forests from the Maule to Los Lagos Regions (Klein and Waterhouse, 2000; Marvaldi and Elgueta, 2006). Approximately $30 \%$ of Aegorhinus spp. are closely linked to species formations of Fagaceae (Elgueta, 1974). Of all the Aegorhinus species, only three are considered major agricultural pests in Chile, namely, A. phaleratus and A. superciliosus associated with berries (Gonzalez, 1989; Prado, 1991; Artigas, 1994; Klein and Waterhouse, 2000; Cisternas, 2002; Aguilera, 2005) and A. nodipennis found mainly in Corylus avellana (European hazelnut). In addition, $A$. albolineatus has been described as an occasional raspberry pest in Rubus idaeus (Cisternas et al., 2000).

The larvae and adult stages of $A$. phaleratus and A. superciliosus, which are reported as being responsible for the damage to their host species, are similar in shape and color; however, they have distinctive characteristics and different geographical distributions (Elgueta, 1993). The first is found from Valparaiso to the Maule Region, whereas the second is established between the Maule and Los Lagos Region. Moreover, both species have a wide host range (Prado, 1991; Elgueta and Marvaldi, 2006 and Parra et al., 2009a).

A. nodipennis is considered one of the most important hypogea insects that affect growing European hazelnut plants due to its frequent presence in farms and its life habits during the larvae stage (Aguilera, 2005). A. superciliosus is found in several fruit tree species (Kuschel, 1951; Parra et al., 2009a) and, together with A. nodipennis, is considered one of the most common pests in Valdivian forests (Artigas, 1994). Interestingly, there is plenty of literature regarding their host species (Kuschel, 1951; Prado, 1991; Artigas, 1994, Klein and Waterhouse, 2000; Cisternas, 2002; Aguilera, 2005; Elgueta and Marvaldi, 2006; Parra et al., 2009a).

Research on Aegorhinus in Chile is mostly focused on its geographic distribution (Aguilera, 1988, 1995; Elgueta, 1993; Artigas, 1994; Arias, 2000), morphological description (Kuschel, 1951; Aguilera, 1988; Aguilera and Rebolledo, 2001; Carrillo et al., 2002) and on damage and control (Kuschel, 1951; Aguilera, 1988, 1995; Prado, 1991; Carrillo, 1993; Elgueta, 1993; Cisternas et al., 2000; France et al., 2000; Parra et al., 2009b; Mutis et al., 2009).

In the La Araucanía Region, the diversity and distribution of species infecting cultivated and wild hosts is unknown; moreover, there is no information regarding possible preferences for certain host species. Therefore, this study aimed at determining the distribution, richness and abundance of Aegorhinus species in different agroecological areas of La Araucanía. Similarly, we identified the hosts where these insect species could be found.

\section{Materials and methods}

\section{Insect sampling}

Sampling was performed at different sites in each agroecological zone of the La Araucanía region $\left(37^{\circ} 35^{\prime}\right.$ and $39^{\circ} 37^{\prime}$ south latitude) as described by Rouanet et al. (1988). At each site, we identified the Aegorhinus species and plants on which the insects were found. A regional map including the agroecological zones and a grid of $25 \times 25$ $\mathrm{km}$ was used for sampling (Figure 1). Each grid was designated by a pair of letters, which were never repeated within the same area. At least 20 sampling points per agroecological zone were randomly chosen, resulting in a total of 122 points for the region. La Araucanía is located in the UTM (Universal Transversal Mercator) zones 18 (central meridian of longitude $-75^{\circ}$ ) and 19 (central meridian of longitude $-69^{\circ}$; Borgel, 1983).

The insect sampling was conducted between September 2008 and April 2009 using three methods: a) shaking the foliage on an entomological umbrella, b) scanning of entomological nets on herbs, shrubs and wild or cultivated trees according to the environmental situation of each sampling station and c) visual observation. Each collected individual was 


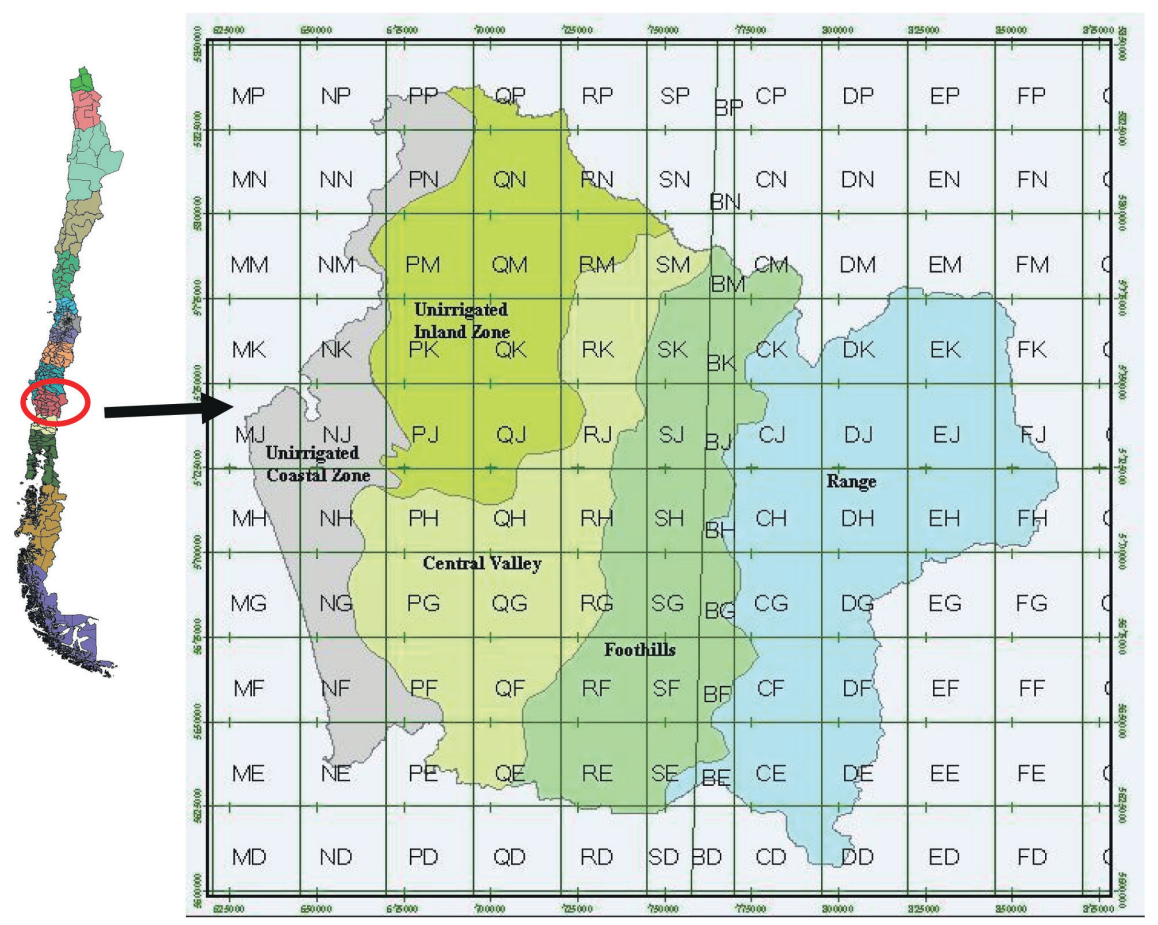

Figure 1. Map of agroecological zones with grids of 25 x $25 \mathrm{~km}$ in La Araucanía region. (Methodology adapted from Pascual and Montserrat, 1988).

recorded with a numerical identifier (ID), collection location, geographical location, altitude and host in which it was found.

\section{Abundance and infestation}

The abundance of insects per plant was estimated according to the following scale:

Low $=$ one to three individuals

Median $=$ four to six

Abundant $=$ seven to ten

Very abundant $=$ more than ten individuals

The percentage of Aegorhinus infestation per plant was determined by the following equation:

$\begin{aligned} & \text { Infestation } \\ & \text { percentage }\end{aligned}=\frac{\text { Total infested trees for species A }}{\text { Total sampled trees for species A }} \times 100$

\section{Distribution map and population indices}

To prepare the distribution maps of the Aegorhinus species, coordinates were obtained at each sampling site using a global positioning system and the GPS III Plus software (GARMIN International, Kansas, USA, 2008). The maps were elaborated from the GPS database in the laboratory of Ordenación y Planificación Territorial of the Facultad de Ciencias Agropecuarias y Forestales of the Universidad de la Frontera using the ArcGIS 9 software program, version 9.2 ArcMap (ESRI USA, 2004). With the obtained data, several population variables such as richness $(\mathrm{S})$, total abundance of individuals $(\mathrm{N})$, relative abundance $(\mathrm{AB} \%)$ and alpha diversity were calculated for each agroecological area using the Shannon-Wiener (H'), Pielou equity index (J) and maximum diversity (H' max) indices (Moreno, 2001).

\section{Results and discussion}

\section{Richness}

Eight Aegorhinus species were identified in the region: A. superciliosus (Guérin), A. nodipennis (Hope), A. schoenherri (Gay \& Solier), A. suturalis (Blanchard), A. ochreolus Kuschel, A. oculatus 
Kuschel, A. silvicola Kuschel and A. bulbifer Kuschel. Of the eight species, three were found in the coastal rain-fed area, three in the interior rain-fed zone, five in the central plain, four in the Andes foothills and six in the Andes mountains. Of all the species, A. superciliosus and $A$. nodipennis were collected in the five assessed agroecological areas (Table 1).

\section{Distribution and abundance}

A total of 11,770 Aegorhinus spp. individuals were counted, and the central plains and the Andean foothills had the highest number of individuals, 6,629 and 4,793, respectively. Most of the specimens were collected from blueberries (Vaccinium corymbosum) and raspberries (R. idaeus) plants. The lowest abundance was found in the Andes mountains, with 69 individuals (Figure 2).

Of all the species found in this study, the two most abundant in the Araucanía region were $A$. superciliosus (9,963 individuals) and $A$. nodipennis (1,692 individuals), which corresponded to $99.02 \%$ of the total registered (Table 1). The abundance of these two species might be explained by their host preference, berry plants, as suggested by several authors (Aguilera, 1988, 1990 and 1995; Parra et al., 2009b). In addition, $A$. ochreolus, $A$. schoenherri, A. suturalis and A. silvicola were considered fairly abundant species, where as the remaining species were considered median.

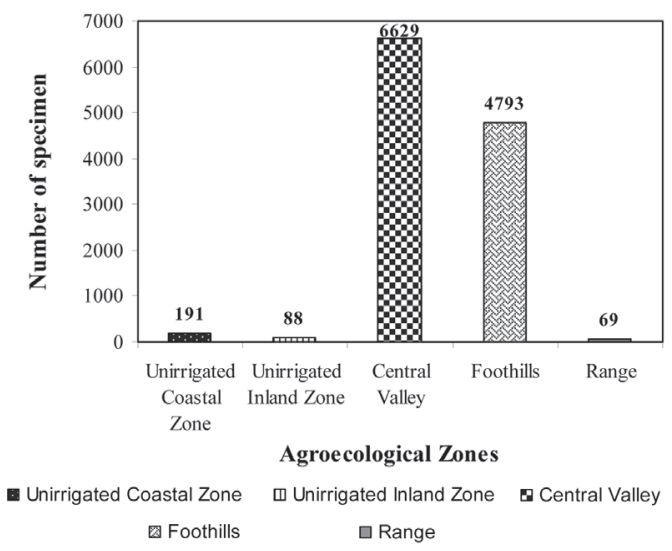

Figure 2. Total number of specimens of the genus Aegorhinus registered in the agroecological zones of La Araucanía region, Chile. Foothills and range correspond the Andes mountain range (see Figure 1).

Regarding the geographic distribution of each species, A. superciliosus dominated in four agroecological zones: the Andes foothills (87.57\%), the coastal rain-fed zone $(85.86 \%)$ and the central plains $(83.77 \%)$, where the highest relative abundances were found. The second most abundant species was $A$. nodipennis, with a higher total abundance in the central plains and in the Andean foothills; however, its higher relative abundance, i.e., the percentage of total individuals, occurred in the mountains and in the interior rain-fed zone. The third most abundant species was $A$. schoenherri, with the highest abundance and relative abundance in the Andes foothills (Table 1).

Interestingly, most Aegorhinus species found in La Araucanía had low population levels and did

Table 1. Total abundance of Aegorhinus registered in the agroecological zones of La Araucanía region.

\begin{tabular}{|c|c|c|c|c|c|c|c|c|c|c|}
\hline \multirow[t]{2}{*}{ Species } & \multicolumn{2}{|c|}{$\begin{array}{l}\text { Unirrigated coastal } \\
\text { zone }\end{array}$} & \multicolumn{2}{|c|}{$\begin{array}{l}\text { Unirrigated inland } \\
\text { zone }\end{array}$} & \multicolumn{2}{|c|}{ Central valley } & \multicolumn{2}{|c|}{$\begin{array}{l}\text { Andes } \\
\text { foothills }\end{array}$} & \multicolumn{2}{|c|}{$\begin{array}{c}\text { Andes } \\
\text { mountain range }\end{array}$} \\
\hline & TE, no. & $\mathrm{AR} \%$ & TE no. & AR $\%$ & TE no. & AR \% & TE no. & AR \% & TE no. & AR $\%$ \\
\hline A. superciliosus & 164 & 85.86 & 47 & 53.41 & 5553 & 83.77 & 4197 & 87.57 & 2 & 2.90 \\
\hline A. nodipennis & 26 & 13.61 & 23 & 26.14 & 1029 & 15.52 & 591 & 12.33 & 23 & 33.33 \\
\hline A. schoenherri & & & & & 1 & 0.02 & & & 23 & 33.33 \\
\hline A. suturalis & 1 & 0.52 & 18 & 20.45 & 13 & 0.20 & 3 & 0.06 & & \\
\hline A. bulbifer & & & & & & & & & 7 & 10.14 \\
\hline A. silvícola & & & & & & & 2 & 0.04 & 13 & 18.84 \\
\hline A. ochreolus & & & & & 33 & 0.50 & & & & \\
\hline A. oculatus & & & & & & & & & 1 & 1.45 \\
\hline Total individuals per zone & \multicolumn{2}{|c|}{191} & \multicolumn{2}{|c|}{88} & \multicolumn{2}{|c|}{6629} & \multicolumn{2}{|c|}{4793} & \multicolumn{2}{|c|}{69} \\
\hline
\end{tabular}

TE, Total specimens; AR, Relative abundance. 
not become pests in orchards or other crops of economic importance in the region. In contrast, the most abundant species were $A$. superciliosus and $A$. nodipennis, which are considered pests with a wide host range and great economic impact on fruit trees in Chile. The presence of these species might be a limiting factor for growing fruit trees in the area.

\section{Diversity}

The area with the lowest species diversity, according to the Shannon-Wiener index, corresponded to the Andes foothills $\left(\mathrm{H}^{\prime}=0.3822\right)$, followed by the coastal rain-fed zone $\left(H^{\prime}=0.4298\right)$, central plains $\left(H^{\prime}=0.4775\right)$, interior rain-fed zone $\left(H^{\prime}=1.0103\right)$ and the Andes mountains $\left(H^{\prime}=\right.$ 1.2109; Table 2). Although the abundance of individuals was higher in these last two areas, their distribution was not even because, in both sectors, $A$. superciliosus represented over $80 \%$ of the individuals collected.

Less diverse areas could be the result of environmental degradation due to anthropogenic factors such as the introduction of exotic plant species, location of urban zones and land use for livestock and agriculture (Vergara et al., 2006). Similarly, the diversity and distribution of other Coleoptera species in the area might reflect the impact of these factors. For example, the most abundant plant species in the coastal rain-fed zone are Pinus radiata and Eucalyptus globulus. In the central plain, blueberries ( $V$. corymbosum) were introduced as an exotic monoculture.

These results are consistent with previous studies (CONAMA, 2002) in which the greater distance among native forest species (with the coastal rain-fed area presenting the greatest distance), the greater intervention they have suffered, so that the natural conditions for establishment and natural flows between species, i.e., biodiversity, considerably declines. However, our results differ from those of Vidaurre et al. (2008), who in a study with dung beetles in Bolivia, described decreased levels of abundance and richness in forests better preserved versus in disturbed habitats. Therefore, disturbed areas supported relatively less abundance and richness than native forests, demonstrating the close relationship that exists with conservation. While this result was coincident with regard to species richness, the abundance differed because the interior rain-fed area and the Andes mountains were the sectors with the lowest levels of exotic plant introduction (CONAMA, 2002) and presented the lowest abundances of Aegorhinus individuals. The persistence of species in natural environments largely depends on the intensity and frequency of spatial disturbances of natural and man-made habitats on the land (Escobar and Chacón de Ulloa, 2000).

According to our results, the lowest Aegorhinus diversity occurred in the Andean foothills,

Table 2. Population parameters of Aegorhinus obtained in the agroecological zones of La Araucanía region, Chile.

\begin{tabular}{lccccc}
\hline Agroecological Zone & $\mathrm{S}$ & $\mathrm{N}$ & $\mathrm{H}^{\prime}$ & $\mathrm{H}^{\prime} \max$ & $\mathrm{J}$ \\
\hline Unirrigated coastal zone & 3 & 191 & 0.4298 & 1.0986 & 0.3912 \\
Unirrigated inland zone & 4 & 88 & 1.0103 & 1.0986 & 0.9196 \\
Central valley & 5 & 6629 & 0.4775 & 1.6094 & 0.2967 \\
Andes foothills & 4 & 4793 & 0.3822 & 1.3863 & 0.2757 \\
Andes mountain range & 6 & 69 & 1.2109 & 1.7918 & 0.6758 \\
\hline
\end{tabular}

S: specific richness; N: total abundance; H': diversity. Shannon-Wiener index; H' max: maximum diversity; J': Pielou equity index. 
and the most diverse sector was the Andean mountains, which, together with the central plain, had the highest species richness. The scarcity of some Aegorhinus species might be the result of the sampling dates because they might have been directly linked to certain stages in the phenology of their hosts. Others, however, appeared to be associated with certain environments, such as $A$. ochreolus, which was found in dense forests of Drymis winteri in the central plain, whereas A. schoenherri and A. silvicola were exclusively related to the Andes mountains.

\section{Altitude and hosts}

With respect to altitude, the most abundant Aegorhinus species ranged from 10 to $1,350 \mathrm{~m}$ in altitude (Figure 3).

The greatest but least diverse abundance, registered in the central plain, was associated with the most abundant species (A. superciliosus and $A$. nodipennis), which colonized a greater number of hosts distributed in lower elevation locations (Kuschel, 1951; Prado, 1991; Artigas, 1994; Klein and Waterhouse, 2000; Cisternas, 2002; Aguilera, 2005; Elgueta and Marvaldi, 2006).

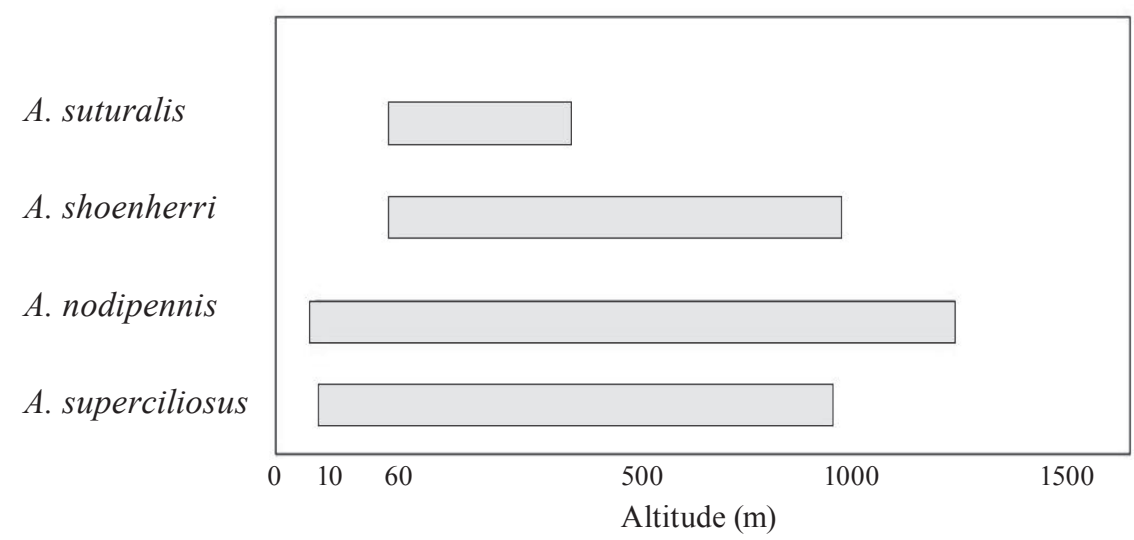

Figure 3. Altitudinal range in which the most abundant Aegorhinus species were found in La Araucanía region, Chile.

Table 3. Altitudinal range and hosts where the especies of Aegorhinus were found in La Araucanía region, Chile.

\begin{tabular}{|c|c|c|}
\hline Species of Aegorhinus & Altitudinal ranges $(\mathrm{m})$ & Hosts \\
\hline A. bulbifer & 360 & Nothofagus dombeyi \\
\hline A. nodipennis & $6-1320$ & $\begin{array}{l}\text { Maytenus boaria }\left({ }^{1}\right), \text { Nothofagus obliqua, Salix viminalis }\left({ }^{1}\right), \\
\text { Aristotelia chilensis, Vaccinium corymbosum, Betula pendula }\left({ }^{1}\right) \text {, } \\
\text { Gevuina avellana, Peumus boldus }\left({ }^{1}\right), \text { Lomatia hirsuta }\left({ }^{1}\right), \text { Drimys } \\
\text { winteri, Nothofagus pumilio. }\end{array}$ \\
\hline A. ochreolus & 132 & Drimys winteri \\
\hline A. oculatus & 805 & Discaria serratifolia $\left({ }^{1}\right)$ \\
\hline A. schoenherri & $54-959$ & Discaria serratifolia y Maytenus boaria $\left({ }^{1}\right)$ \\
\hline A. silvícola & 959 & Nothofagus antartica $\left({ }^{1}\right)$ \\
\hline A. superciliosus & $6-908$ & $\begin{array}{l}\text { Acacia dealbata }\left({ }^{1}\right), \text { Maytenus boaria, Rubus ulmifolius, Salix } \\
\text { viminalis, Vaccinium corymbosum, Rosa moschata, Nothofagus } \\
\text { obliqua }\left({ }^{(}\right) \text {, Nothofagus dombeyi, Nothofagus pumilio }\left({ }^{1}\right) \text {, Populus } \\
\text { alba }\left({ }^{(}\right) \text {, Drimys winteri, Rubus idaeus, Betula pendula }\left({ }^{(1)} \text {, Cynara }\right. \\
\text { scolymus }\left({ }^{(}\right), \text {Discaria serratifolia }\left({ }^{1}\right), \text { Lomatia hirsuta }\left({ }^{(}\right)\end{array}$ \\
\hline A. suturalis & $54-580$ & Lomatia hirsuta $\left({ }^{1}\right)$, Rubus idaeus $\left({ }^{1}\right)$, Salix viminalis $\left({ }^{1}\right)$ \\
\hline
\end{tabular}

\footnotetext{
${ }^{1}$ New record of host for the species.
} 
In the highest areas of the region, except for the mountains, plant diversity was lower because exotic forest species (e.g., pine and eucalyptus) have been uniformly planted (CONAMA, 2002). In the Andes mountain range, the predominant vegetation corresponded to forests of Nothofagus, Araucaria araucana and Rhamnaceae species, such as Discaria serratifolia, which presented Aegorhinus species closely associated to only one host; similarly, A. schoenherri was found in D. serratifolia and Maytenus boaria (Table 3).

There were eight new hosts for A. superciliosus, but its presence on Acacia dealbata was probably accidental. A. nodipennis was observed on five new hosts, and it was abundant in M. boaria, Betula pendula and Salix viminalis. A. suturalis was first found in Lomatia hirsuta and R. idaeus, which constituted unknown hosts for this species.
A. schoenherri was associated with hosts of the Rhamnaceae family. These results are coincident with those of Arias (2000), who mentioned Discaria serratifolia (chacay) as host plant, but it was also found in M. boaria, which would be a new host for this species.

Regarding host preference, we found the highest presence of Aegorhinus in the following species: $M$. boaria $(79 \%)$, Rosa moschata $(54.2 \%)$, D. winteri (46.3\%), Rubus ulmifolius (44.4\%) and L. hirsuta (44.1\%; Table 4). Despite being one of the species with the greatest Aegorhinus presence in the city of Temuco, B. pendula only reached $15.8 \%$ at the regional level. Consistent with our results, Parra et al. (2009a) reported M. boaria, D. winteri and $R$. ulmifolius, among others, as hosts of $A$. superciliosus. V. corymbosum and $R$. idaeus were excluded from the analysis because the insects counted in

Table 4. Total number of hosts for the Aegorhinus species sampled, infestation percentage and species of Aegorhinus.

\begin{tabular}{|c|c|c|c|c|c|c|c|c|c|c|c|c|}
\hline Hosts & Total plants & $\% \mathrm{AI}$ & APAAI & 1 & 2 & 3 & 4 & 5 & 6 & 7 & 8 & Total \\
\hline Maytenus boaria & 266 & 79 & 2.17 & 414 & 41 & & & & & & & 455 \\
\hline Acacia dealbata & 6 & 17 & 1.02 & 1 & & & & & & & & 1 \\
\hline Nothofagus oblicua & 130 & 8 & 1.53 & 2 & 13 & & & & & & & 15 \\
\hline Lomatia hirsuta & 68 & 44.1 & 1.17 & 3 & 5 & & 27 & & & & & 35 \\
\hline Rubus ulmifolius & 376 & 44.4 & 0.9 & 143 & 1 & & & & & & & 144 \\
\hline Rosa moschata & 83 & 54.2 & 1.02 & 46 & & & & & & & & 46 \\
\hline Salix viminalis & 41 & 19.5 & 3.25 & 3 & 20 & & 3 & & & & & 26 \\
\hline Populus alba & 36 & 27.8 & 1 & 10 & & & & & & & & 10 \\
\hline Nothofagus dombeyi & 35 & 43 & 3 & 36 & & & & 9 & & & & 45 \\
\hline Aristotelia chilensis & 20 & 45 & 1.55 & 12 & 2 & & & & & & & 14 \\
\hline Drimys. winteri & 205 & 46.3 & 1.04 & 2 & 64 & & & & & 33 & & 99 \\
\hline Peumus boldus & 17 & 12 & 1.47 & & 3 & & & & & & & 3 \\
\hline Vaccinium corymbosum & Orchard & & & 9194 & 1506 & & & & & & & 10700 \\
\hline Betula pendula & 76 & 15.8 & 2.58 & 10 & 21 & & & & & & & 31 \\
\hline Geviina avellana & 5 & 20 & 1 & & 1 & & & & & & & 1 \\
\hline Nothofagus antartica & 21 & 5 & 12.38 & & & & & & 13 & & & 13 \\
\hline Discaria serratifolia & 95 & 20 & 1.37 & 1 & & 24 & & & & & 1 & 26 \\
\hline Nothofagus pumilio & 37 & 30 & 1.62 & 1 & 17 & & & & & & & 18 \\
\hline Rubus ideaus & 5 rows & & & 100 & & & 5 & & & & & 105 \\
\hline Cynara scolymus & 25 & 64 & 1.88 & 30 & & & & & & & & 30 \\
\hline Eucaliptus globulus & 13 & 8 & 1 & & 1 & & & & & & & 1 \\
\hline
\end{tabular}

\% IA: infested trees; AAAIT: average abundance of Aegorhinus per infected trees; 1: A. superciliosus; 2: A. nodipennis; 3: A. schoenherri; 4: A. suturalis; 5: A. bulbifer; 6: A. silvicola; 7: A. ochreolus and 8: A. oculatus. 
these host species corresponded to sporadic catches made by farm workers (Table 4).

Aegorhinus specimens were not found in A. araucana, Citrus sinensis, Crinodendron patagua, Cryptocaria alba, Cupressus macrocarpa, Eriobotrya japonica, Eucryphia cordifolia, Luma apiculata, Malus sp., Persea lingue, Prunus cerasus and Prunus domestica. However, there are reports on Cryptocaria alba as a host of A. phaleratus; Eucryphia cordifolia as a host of $A$. nodipennis; Malus domestica as a host of $A$. nodipennis, $A$. phaleratus and $A$. superciliosus; Prunus cerasus as a host of $A$. phaleratus and $A$. superciliosus; and $P$. domestica as a host of $A$. nodipennis, $A$. phaleratus and A. superciliosus (Kuschel, 1951; Prado, 1991; Artigas, 1994; Arias, 2000; Klein and Waterhouse, 2000; Cisternas, 2002; Aguilera, 2005; Elgueta and Marvaldi, 2006).

\section{Maps}

The distribution of species considered most important as agricultural pests, $A$. superciliosus and
A. nodipennis (Figure 4), and the least abundant or of less agricultural importance (Figure 5) were represented separately in maps of the $\mathrm{La}$ Araucanía region. The agroecological zones were illustrated in both maps.

Regarding the ecosystem associated with these species, A. bulbifer was found in areas of arborescent matorral and open native forest. A. suturalis was found in open areas of open arborescent matorral and open prairie matorral. A. silvicola and $A$. schoenherri were associated with semi-dense adult native forest and open prairie matorral. $A$. oculatus was associated with semi-dense regrowth areas and open matorral. A. ochreolus was described in areas of perennial prairie with open native forests. A. superciliosus and A. nodipennis were distributed in areas strongly dominated by arborescent matorral.

According to our results, the species of Aegorhinus in the Araucanía region were $A$. bulbifer, $A$. nodipennis, A. ochreolus, A. oculatus, A. schoenherri, A. silvicola, A. superciliosus and A. suturalis. Six of these species, A. superciliosus, A. nodipen-
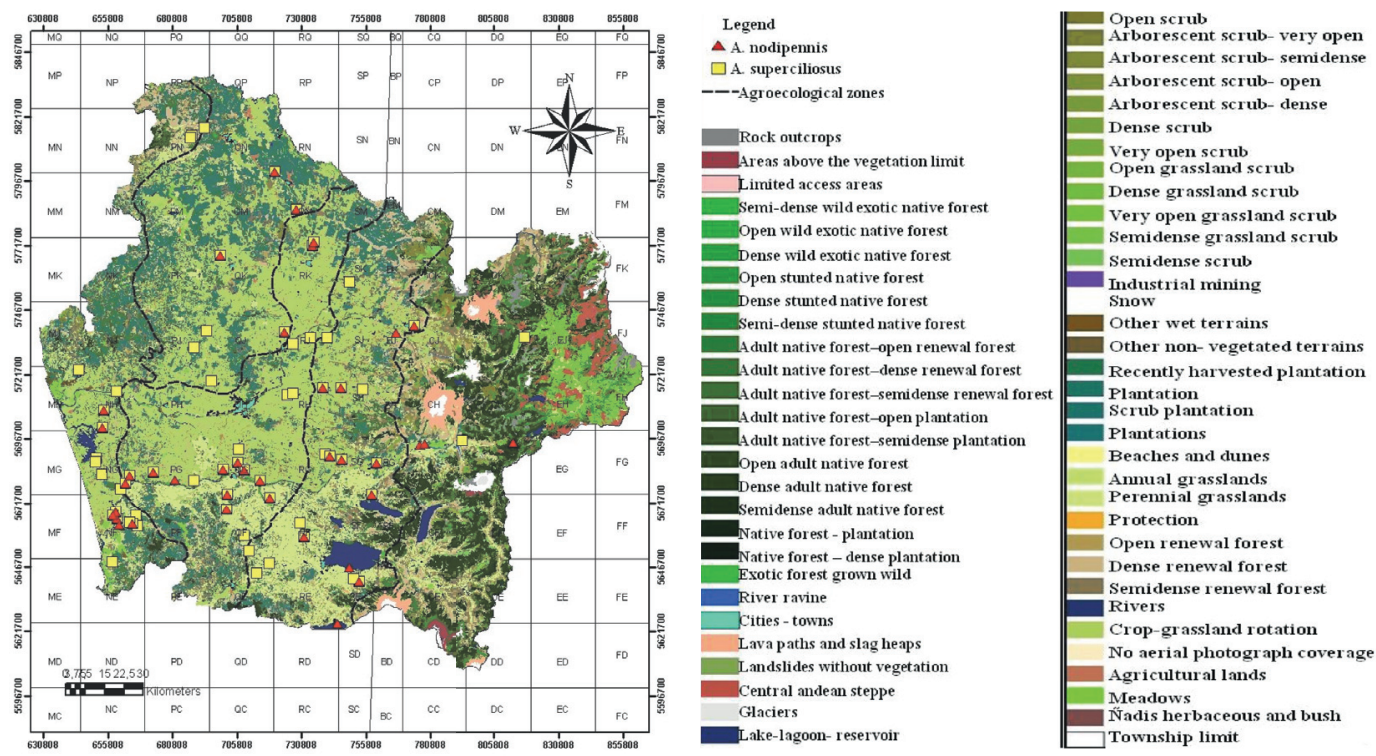

Figure 4. Distribution of Aegorhinus superciliosus and A. nodipennis in different ecosystems of the La Araucanía region, Chile. 
nis, $A$. suturalis, A. silvicola, $A$. oculatus and $A$. schoenherri presented new hosts in La Araucanía region. Thus, the most novel findings of this study were the following: 1) A. superciliosus was found on A. dealbata, N. obliqua, N. pumilio, Populus alba, Betula pendula, Cynara scolymus, Discaria serratifolia and Lomatia hirsuta; 2) A. nodipennis was found on M. boaria, Salix viminalis, Betula pendula, Peumus boldus and Lomatia hirsuta; 3) A. suturalis was found on Lomatia hirsuta, $R$. idaeus and Salix viminalis; 4) A. silvicola was found on N. antartica; 5) A. oculatus was found on Discaria serratifolia and 6) A. schoenherri was found M. boaria.

\section{Acknowledgements}

The authors would like to acknowledge the financial support provided by Project DIUFRO DI10-101 from the University of La Frontera and project FONDECYT 1070270.

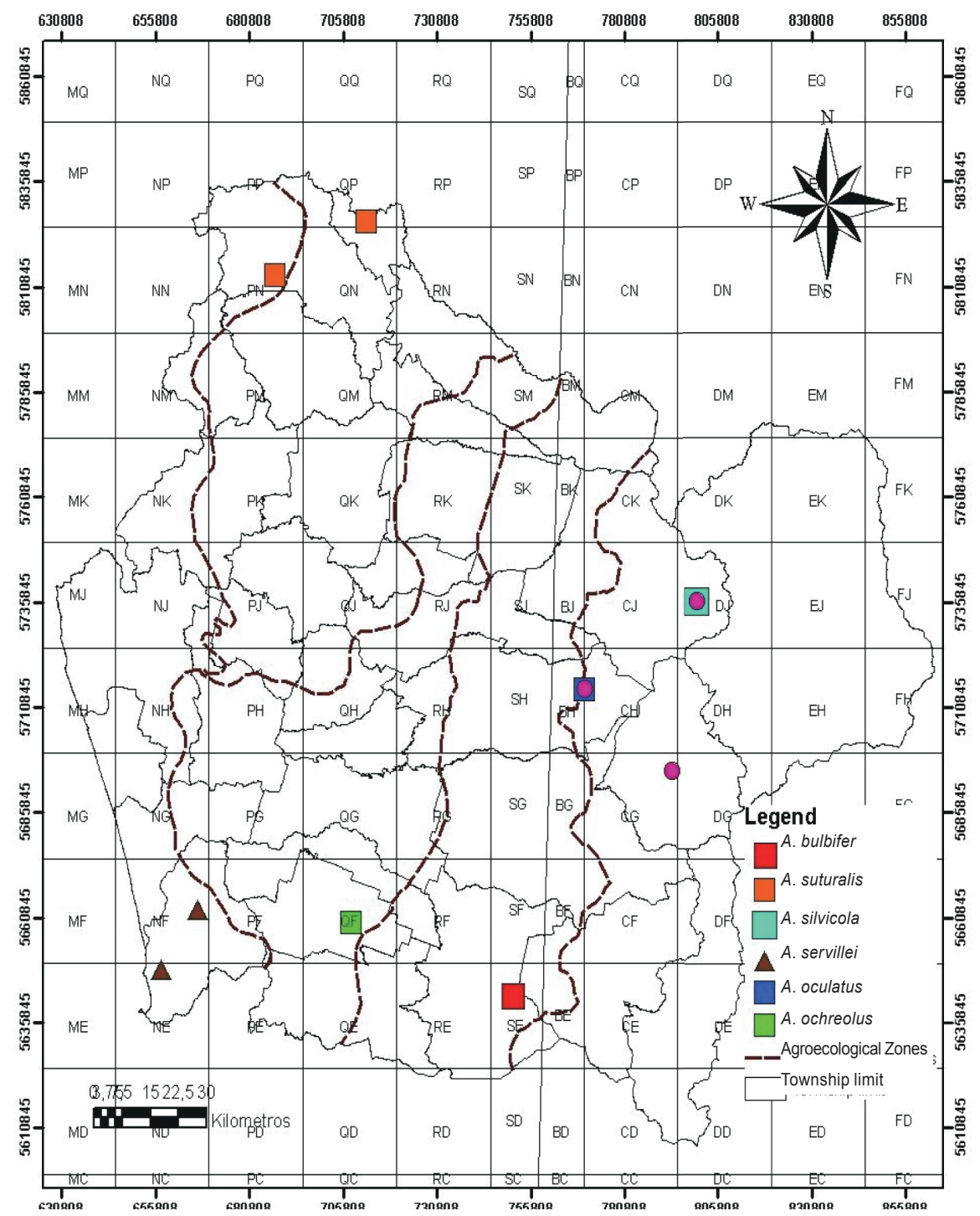

Figure 5. Map of Aegorhinus species distribution with less agricultural importance in La Araucanía region, Chile. 


\title{
Resumen
}

\begin{abstract}
A. Zavala, M. Elgueta, J. Abarzúa, A. Aguilera, A. Quiroz y R. Rebolledo. 2011. El género Aegorhinus, diversidad y distribución en la Región de La Araucanía, Chile, con especial referencia a $A$. superciliosus y $A$. nodipennis. Cien. Inv. Agr. 38(3): 367-377. En la región de La Araucanía, área productora de berries, aún se desconocen aspectos relevantes del comportamiento de los integrantes del género Aegorhinus, considerados plagas importantes en estos cultivos, por lo que este estudio tuvo como objetivos determinar la distribución, riqueza y abundancia de estas especies en las zonas agroecológicas de La Araucanía y sus hospederos. Los puntos donde se encontraron estas especies fueron representados en un mapa dividido en cuadrículas de $25 \mathrm{~km}$ x $25 \mathrm{~km}$. Se registraron ocho especies de Aegorhinus, siendo Aegorhinus superciliosus y Aegorhinus nodipennis las especies más abundantes. La diversidad se analizó a través del índice de Shannon-Wiener; y la equiparabilidad con el índice de Pielou. La zona agroecológica con mayor diversidad para la región correspondió a la cordillera, sin embargo en el llano central se registró la mayor abundancia de individuos. En este trabajo se dan a conocer nuevos hospederos para seis de las ocho especies encontradas en la región.
\end{abstract}

Palabras clave: Aegorhinus, Coleoptera, hospederos, zonas agroecológicas.

\section{References}

Aguilera, A. 1988. Plagas del arándano en Chile. p. 109-131. In: Lobos, W. (ed.). Seminario: El cultivo del arándano. INIA Carillanca, Temuco, Chile.

Aguilera, A. 1990. Insectos fitófagos cuarentenarios asociados a frutales menores en la IX Región. IPA Carillanca, Temuco, Chile. p. 3: 7-11.

Aguilera, A. 1995. Control selectivo de plagas en frutales de la zona sur. p. 141-180. In: Aguilera, A., O. Andrade, J. Díaz, N. Espinoza, R. Galdames, and H. Norambuena. (eds.). Seminario de Protección Vegetal. INIA Carillanca, Temuco, Chile.

Aguilera, A. 2005. Plagas subterráneas del avellano europeo. Revista Tierra Adentro 62: 16-18.

Aguilera, A., and R. Rebolledo. 2001. Estadios larvarios de Aegorhinus superciliosus (Guérin, 1830) (Coleoptera: Curculionidae). Rev. Chilena Ent. 28: 5-8.

Arias, E. 2000. Coleópteros de Chile. Fototeknika Ltda. Santiago, Chile. 209 pp.

Artigas, J. 1994. Entomología Económica: insectos de interés agrícola, forestal, médico y veterinario (nativos, introducidos y susceptibles de ser introducidos). Eds. Universidad de Concepción. Concepción, Chile. 1126 pp.
Borgel, R. V. 1983. Fundamentos geográficos del Territorio Nacional. Geografía de Chile IGM. Edit. IGM. Santiago, Chile. 247 pp.

Carrillo, R. 1993. Plagas insectiles en arbustos frutales menores. p. 63-86. In: Barriga, P. and M. Neira. (eds.). Cultivos no tradicionales. Uniprint. Valdivia, Chile.

Carrillo, R., H. Pérez, and M. Neira. 2002. Comportamiento de oviposición de Aegorhinus superciliosus (Guérin) (Coleoptera: Curculionidae). Agro Sur 30: 47-50.

Cekalovic, T. 1970. Nueva especie para el género Aegorhinus Erichson (Coleoptera: Curculionidae). Bol. Soc. Biol. de Concepción 42: 55-57.

Cisternas, E. 2002. Curculiónidos, insectos plagas de berries. Revista Tierra Adentro 47: 14-15.

Cisternas, E., A. France, L. Devotto, and M. Gerding. 2000. Insectos, ácaros y enfermedades asociadas a la frambuesa. Instituto de Investigaciones Agropecuarias. Chillán, Chile. Boletín No 37. 126 pp.

CONAMA. 2002. Estrategia regional de conservación y uso sustentable de la biodiversidad. Región de La Araucanía, Chile. Corporación Nacional del Medio Ambiente (CONAMA). Santiago, Chile. 171 pp.

Elgueta, M. 1974. Una nueva especie de Aterpinae (Coleoptera, Curculionidae). Rev. Chilena Ent. 8: 133-134. 
Elgueta, M. 1993. Las especies de Curculionoidea (Insecta: Coleoptera) de interés agrícola en Chile. Santiago, Chile. Museo Nacional de Historia Natural 48: 1-79. (Publicación Ocasional).

Elgueta, M. 2000. Dos especies nuevas de Aegorhinus (Coleoptera: Curculionidae: Aterpini) de Chile. Acta Ent. Chilena 24: 7-18.

Elgueta, M., and A. Marvaldi. 2006. Lista sistemática de las especies de Curculionoidea (Insecta: Coleoptera) presentes en Chile, con su sinonimia. Santiago, Chile. Boletín del Museo Nacional de Historia Natural 55: 113-153.

Escobar, F., and P. Chacon de Ulloa. 2000. Distribución espacial y temporal en un gradiente de perturbación de la fauna de coleópteros coprófagos (Scarabaeidae, Aphodiinae) en la Reserva Natural La Planada, Narino, Colombia. Revista de Biología Tropical 48 (4):961-975.

France, A., M. Gerding, and A. Sandoval. 2000. Patogenecidad de una colección de cepas nativas de Metarhizium spp. y Beauveria spp. en Aegorhinus superciliosus, Asynonychus cervinus y Otiorhynchus sulcatus. Agric. Téc. (Chile) 60: 205-215.

González, R. 1989. Insectos y ácaros de importancia agrícola y cuarentenaria en Chile. Impresora y Editora Ograma S.A. Santiago, Chile. 310 pp.

Klein, C., and D. F. Waterhouse. 2000. The distribución and importance of arthropods associated with agriculture and forestry in Chile. ACIAR Monograph 68. Canberra, Australia. 231 pp.

Kuschel, G. 1951. La subfamilia Aterpinae en América. Rev. Chilena Ent. 1: 205-244.

Moreno, C. 2001. Métodos para medir la biodiversidad. Centro de Investigaciones Biológicas. Universidad Autónoma del Estado de Hidalgo, México. Vol. 1. 83 pp.

Morrone, J.J., and S. Roig-Juñent. 1999. Synopsis and cladistics of the American Aterpini (Coleoptera: Curculionidae, Cyclominae). Ent. Scand. 30: 417-434.
Mutis, A., L. Parra, R. Palma, F. Pardo, F. Perich, and A. Quiroz. 2009. Evidence of contact pheromone use in mating bahavior of the raspberry weevil (Coleoptera: Curculionidae). Environmental Entomology 38: 192-197.

Parra, L., A. Mutis, A. Aguilera, R. Rebolledo, and A. Quiroz. 2009a. Estado del conocimiento sobre el cabrito del frambueso (cf), Aegorhinus superciliosus (Guérin) (Coleoptera: Curculionidae). Idesia 27(1): 57-65.

Parra, L., A. Mutis, R. Ceballos, M. Lizama, F. Pardo, F. Perich, and A. Quiroz. 2009b. Volatiles released from Vaccinium corymbosum were attractive to Aegorhinus superciliosus (Coleoptera: Curculionidae) in anolfactometric bioassay. Environmental Entomology 38: 781-789.

Pascual, F. and V.J. Montserrat. 1988. Cartografiado Biológico, p. 63 - 77. In: Bases para un curso práctico de Entomología. Asociación española de Entomología. Salamanca, España. 754 pp.

Prado, E. 1991. Artrópodos y sus enemigos naturales asociados a plantas cultivadas en Chile. Estación Experimental La Platina (INIA), Santiago, Chile. Serie Boletín Técnico No 169. 203 pp.

Rouanet, J. L., O. Romero, and R. Demanet, R. 1988. Áreas agroecológicas en la IX Región: Descripción. Estación Experimental Carillanca. Temuco, Chile. IPA Carillanca. 1: 18-23.

Vergara, O., V. Jerez, and L. Parra. 2006. Diversidad y patrones de distribución de coleópteros en la Región del Biobío, Chile: una aproximación preliminar para la conservación de la diversidad. Revista Chilena de Historia Natural 79(3): 369388.

Vidaurre, T., L. González, J. Ledezma. 2008. Escarabajos coprófagos (Scarabaeidae: Scarabaeinae) del Palmar de las Islas, Santa Cruz-Bolivia. Kempffiana 4: 3 - 20. 
